Volume 11 Number 2, April-June 2017: pp. 150-172

Copyright (c) 2015-2016 FIAT JUSTISIA. Faculty of Law, Lampung University, Bandarlampung, Lampung, Indonesia. ISSN: 1978-5186 | e-ISSN: 2477-6238.

Open Access: http://iurnal.fh.unila.ac.id/index.php/fiat

Fiat Justisia is licensed under a Creative Commons Attribution 4.0 International License, which permits unrestricted use, distribution, and reproduction in any medium, provided the original work is properly cited.

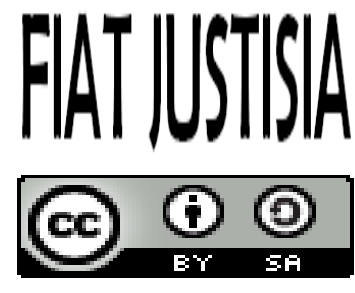

\title{
Indonesian Fisheries Policy Reform: Compliance with Stringent Food Safety Requirement Of Importing Countries
}

\author{
Fauna Alwy \\ University of Khairun \\ fauny72@yahoo.com
}

\begin{abstract}
The main objective of this research is to discover the idea of innovation of Indonesia's legislation system on food security/seafood which has been heavily influenced by trade relations between Indonesia and the European Union as a group of major importing countries. This is a case study that largely examines and presents trade disputes between Indonesia and some major importing countries, especially with the EU countries as a major group of country importers of fishery products and seafood from Indonesia. The various disputes and complaints found in this case study demonstrate the fact that the marine fisheries sector as one of Indonesia's mainstay sectors has a very potential economic value for the country's foreign exchange earnings. There is a very close relationship between the fisheries sector with the fulfillment of people's living needs as well as the development of the economic sector in general, including food safety aspects. This should be addressed appropriately and efficiently by the government by adjusting and even updating laws and regulations in this sector by the international food standard/food security; given the numerous demands and rejection of most of Indonesia's trading partner countries in this sector.
\end{abstract}

Keyword: Indonesian Fisheries, Policy Reform, Compliance, Food Safety Requirements, Importing Countries.

\section{A. Introduction}

The Ministry of Maritime Affairs and Fisheries of The Republic of Indonesia has announced a US\$5 billion revenue target from fish products 
exports by 2006. It is doubled than the 2004 estimation of US\$ 2.14 billion in revenue. This target can be achieved by expanding to the new markets, reducing export barriers and developing marine ornamental fish as a top export commodity. ${ }^{1}$, fishery products might be the most prospective export commodities shortly as it plays an important role into the development process about some key factors related: livelihoods and the development including food security, the subsistence of artisanal fishing societies and invention of foreign exchange earnings.

However, as a result of increased trade in fishery commodities, seafood safety has been a complex issue in the international trading system. The increasingly stringent and technologically challenging sanitary and phytosanitary, further it called SPS requirements, mostly from importing developed countries, may limit the export opportunities of developing countries. The majority of the significant food/sea-food safety issues in international trade today affected the ability to develop countries to expand their market access. ${ }^{2}$ Indonesia, for instance, has experienced the financial loss from tuna products in 2005 , for approximately 30 percent of its total production, ${ }^{3}$ as a result of alert notifications imposed by European Union.

This paper provides a case study of trade between Indonesia with its major trading partners, particularly EU, on fish and fishery products. It will present the analysis of how the prevalence of stringent SPS standard on seafood safety impact on Indonesian market access on fish and fishery products. From the legal point of view, it will then examine the innovative policies on fishery sector, launched by the Indonesian government, to gain back the economic potential of fish and fishery commodities as a large contributor to the country's foreign exchange income. Lastly, trade relationship between Indonesia and the European Union on fisheries sector will be analyzed to grasp the idea on how the innovation of Indonesian regulation system on food/seafood safety is strongly influenced by this relationship.

\section{B. Discussion}

\section{General Review of the SPS Measures on Food/Seafood Safety}

Sanitary and Phytosanitary measures were intended to protect the animal, human, or plant life or health within the territory of the adopting state from the risk of additives, contaminants, toxins or other pathogenic organisms. ${ }^{4}$

\footnotetext{
${ }^{1}$ FAO, Fisheries Global Information System, National Aquaculture Overview - Indonesia, October 2006

${ }^{2}$ Anderson, Kym et al. The Economic of Quarantine and the SPS Agreement, (2001), p. 287

${ }^{3}$ Above, n.1. Id.

${ }^{4}$ Matsushita, Mitsuo, et al. The World Trade Organization-Law, Practice and Policy (2002)

59. Quoted from: Agreement on the Application of Sanitary and Phytosanitary Measures,
} 
"They contained measures intended to avoid any infection arising from foodstuffs, plant or animal (including fish, wild fauna, and flora), and from all diseases, organisms, and parasites from forests."

In the context of WTO, the objective of the SPS agreement is to allow the existence of the legitimate protection of life and health, which in turn prevents the implemented measures from becoming a form of protectionism in disguise. ${ }^{6}$ In other words, the SPS agreement is aspired to balance the national interest in human, animal and plant safety with the international trade interest. Hence the benchmarks are set up for the member states in the sanitary area and recommend scientific evidence, harmonization, equivalence and mutual recognition, risk assessment, and transparency. ${ }^{7}$

In international fisheries trade, the above provisions can be applied in three ways:

a. Firstly, by adopting standards agreed in the relevant international institutions, the Codex Alimentarius for instance, and implementing in the national sanitary and phytosanitary regulation. ${ }^{8}$ This is a reflection of the principle of harmonization.

b. Secondly, applying the concept of equivalence or mutual recognition which is referred that members shall accept the sanitary or phytosanitary measures of other members as equivalent, even if these measures differ from their own or from those used by other members trading in the same product, if the exporting member can prove that its measures reach the appropriate level of sanitary or phytosanitary protection that required by importing member. ${ }^{9}$ However, it might be discriminatory to the developing countries as they find it difficult and burdensome to prove that their standard is equivalent. ${ }^{10}$

c. Thirdly, based on article 5 of the SPS agreement, members are required to apply either scientific proof or appropriate risk measurement if they

reprinted in WTO, The Legal Text: The Result of The Uruguay Round of Multilateral Trade Negotiations 59 (1999) [Hereinafter SPS Agreement]

${ }^{5}$ Landau, Alice International Trading System, (2005), p. 19

${ }^{6}$ Friis, M. Jensen, 'Reviewing the SPS Agreement: A Developing Country Perspective', (2002), The Royal Veterinary and Agricultural University, 5

${ }^{7}$ Above, n.4, p. 18

8 Ruckes, E. 2000. Evolution of the International Regulatory Framework Governing International Trade in Fishery Products. Paper presented at the International Institute of Fisheries Economic and Trade 2000. Available online at http://oregonstate.edu/dept/IIFET/2000/abstracts/ruckes.html

${ }^{9}$ Agreement on the Application of Sanitary and Phytosanitary Measures, reprinted in WTO, The Legal Text: The Result of The Uruguay Round of Multilateral Trade Negotiations 59 (1999) [ Hereinafter SPS Agreement] article 4:1

${ }^{10}$ ICTSD - The International Centre for Trade and Sustainable Development, Fisheries, International Trade and Sustainable Development: Policy Discussion Paper, (2006) 42 
intend to rely on their domestic standards rather than harmonization or equivalence principles. ${ }^{11}$

Furthermore, if member countries preferred to implement SPS measures with their Appropriate Levels of Protection (ALOP), in such circumstances, they are obliged to conduct a specific scientific justification. Members are required to prove that such measures are appropriate under the circumstances while considering risk assessment techniques structured by the international standards organizations. ${ }^{12}$ Risk assessment under the SPS agreement is defined as:

a. The evaluation of the chances of entry, establishment or spread of a pest or disease within their territory and the associated potential biological and economic consequences;

b. The evaluation of the potential for harmful effect on human or animal health arising from the presence of additives, contaminants, toxins or disease-causing organisms in food, beverages or feedstuffs. ${ }^{13}$

In practice, some member countries may provide standards that are more stringent and trade restrictive than necessary. Although it is allowed by the agreement regarding the appropriate scientific evidence provided by importing countries to protect human beings, animals, plants, and health within its territory ${ }^{14}$, this also triggers a misuse of measures for protectionist purposes. Pardo Quintillan, moreover asks:

"How to ensure that consumers of one's country obtain healthy food according to the standards considered to be appropriate, and at the same time how to ensure that health regulations and those relative to health are not utilized for protecting local producers." 15

Thus, to prevent the occurrence of protectionist, transparency should be widely recognized by importing countries in conducting their SPS measurements. At the WTO, members, therefore, are required to establish notification points related to the new SPS measures, as well as inquiry points directed to the WTO. Otherwise, members are also encouraged to be transparent in sharing information associated with the standards and the quality assurances used in the product grading, testing, and processing. ${ }^{16}$ Related to fish and fishery products, in 2003, EU made about 545 SPS notifications for fish, crustaceans, and mollusks addressed to Asia, Africa,

\footnotetext{
${ }^{11}$ Ibid., p.4.

${ }^{12}$ Ibid., p.1, p.110

${ }^{13}$ Ibid., p.9.Id.

${ }^{14}$ Ibid., p. 8

${ }^{15}$ Ibid., article 4:1

${ }^{16}$ United Nations Conference on Trade and Development, Commission on Trade in Goods and Services, and Commodities, Expert Meeting on Dynamic and New Sectors of World Trade, Trade and Development board (2006)
} 
and South America. Mostly of EU notifications at that time were associated with microbial contaminations, but now the notifications are mainly concerning chemical risks, such as heavy metal contaminations. ${ }^{17}$ Among the various commodities, shrimp gathered the highest number of notifications followed by fish.

However, certain developing countries have noted that the notifications procedure does not work appropriately. Even though the developed countries frequently notify changes in legislation, they rarely take comments made by the developing countries into their consideration. ${ }^{18}$ The SPS committee therefore in 2004 adopted specific measures to revise the notification system that is required members to engage in bilateral consultations if an exporting country recognized considerable difficulties in complying with proposed legislation. ${ }^{19}$ However, "no country has so far made use of this new mechanism." 20

A latter reality may happen when the developing countries tend to focus on export market maximization rather than to engage in lengthy bilateral consultation that perhaps has a consequential result in the loose of market share. Moreover, the high dependency of developing countries on the developed countries export market may, in turn, enervate their bargaining position in the international trading system. The latest data from FAO shows that the developed countries "account for $81 \%$ of all imports of fish-based products, in value terms". ${ }^{21}$

The above phenomena can also be seen in the preference of food safety standard. While the implementation of HACCP (Hazard Analysis and Critical Control Point) $)^{22}$ is voluntarily in nature, some countries have established mandatory HACCP schemes for specific products include Australia, Canada, Japan, the USA and the European Union. ${ }^{23}$ As a consequence, their trading partners who are notable as developing countries like Indonesia, Malaysia, and Thailand were imposed to implement HAACP as their food/seafood safety standard. The US-Food and Drugs Agency

\footnotetext{
${ }^{17}$ Ibid., p.9.

${ }^{18}$ Ibid., p.5, p.28

${ }^{19}$ Ibid., p.7.

${ }^{20}$ Ibid., p.9, p.43

${ }^{21}$ FAO, Fish exports by developing countries help combat hunger, but better management needed, Newsroom, (2006)

${ }^{22}$ Cato, JC., World (c), 20018, nsgd.gso.uri.edu -- HACCP (Hazard Analysis and Critical Control Point) is an international recognized, science based seafood safety system, which is used to help ensure the manufacture of safe food products. This system has been used as a standard to reduce or eliminate potential biological, chemical and physical seafood safety hazards, including those triggered by cross contamination.

${ }^{23}$ Zakariah Z. Maharani, 'The Implementation of Hazard Analysis and Critical Control Point (HAACP) by the Seafood Industry in Malaysia
} 
(FDA), for example, from 18 December 1997, has required each Indonesian Fisheries Processing Unit (UPI) to apply the HAACP for their fishery export commodities. ${ }^{24}$ Thus, it can be assumed that widespread recognition of food/sea-food safety standards among developing countries is mainly stimulated by a strong desire to gain market access rather than health or environmental concerns.

\section{Compliance Standards of Seafood Safety: Challenges for Indonesian Fisheries Export}

As the biggest archipelagic state in the world, Indonesia owned more than 17,000 islands and coastline of about $81,000 \mathrm{~km}$. Marine accounts for $75 \%$ of the Indonesian territory, and about $26,606,000$ hectare of this area can potentially be utilized for aquaculture development for export purposes as well as for domestic consumption. ${ }^{25}$ In 2002, as can be seen in the table below, Indonesia was in the fourth position of the top capture fisheries producers after China, Peru, and the United States. ${ }^{26}$

Leading capture fisheries producers (2003)

\begin{tabular}{|l|l|l|l|}
\hline Country & \% of Total & Country & \% of Total \\
\hline China & 18.6 & Chile & 4 \\
\hline Peru & 6.75 & $\begin{array}{l}\text { Russian } \\
\text { Federation }\end{array}$ & 3.6 \\
\hline $\begin{array}{l}\text { The United } \\
\text { States }\end{array}$ & 5.5 & Thailand & 3 \\
\hline Indonesia & 5 & Norway & 3 \\
\hline Japan & 5 & Philippines & 2.4 \\
\hline India & 4 & Iceland & 2 \\
\hline
\end{tabular}

Source: FAO (2003)

Furthermore, as a result of "innovations in technology, expansions of aquaculture area and availability of suitable quality fish seeds," 27 in 2003, Indonesia's total aquaculture production reached a value at US\$1,715 901 000. At the same period, Indonesian export performance on fishery products, including export from capture and culture fisheries, raised gradually from

\footnotetext{
${ }^{24}$ Mangunsong, Setia, 'Roadmap Manajemen Mutu Hasil Perikanan (The Roadmap of the Fisheries Quality Management System)'.

${ }^{25}$ Nurdjana, Made L. (2006), 'Indonesia Aquaculture Development', Paper presented at the RCA International Workshop on Innovative Technologies for Eco-Friendly Fish Farm Management and Production of Safe Aquaculture Food, Bali. p. 56. Accessed in www.agnet.org--htmlarea_file--library

${ }^{26}$ Ibid., p.9.

${ }^{27}$ FAO, Fisheries Global Information System, National Aquaculture Overview - Indonesia (2006)
} 
644,604 tonnes to 857,783 tonnes in 2003. By value, it increased from US\$ $1,605,421$ thousand in 1999 to US\$ $1,643,542$ thousands in 2003 , or about 0.66 percent annually.

Indonesia has the varieties of fish species and processed products that are in high demand overseas, that identified by FAO as follow:

[.....] shrimp (unfrozen, frozen and canned), crabs (unfrozen, frozen and canned), frog legs (fresh or chilled), seaweed (dried), ornamental fish (freshwater and mariculture), molluscs (scallops and snails), pearls and others, including capture products such as tuna, jellyfish and coral fish as well as fish fat/oil and shrimp crackers. ${ }^{28} \quad$ Responsively, Indonesian Ministry of Maritime and Fisheries had put tuna, shrimp, and seaweed in the priority of development in "the revitalization of fishery products." 29

\section{a. Shrimp}

Despite a tendency to decrease in the average price by 6.24 percent for every year, shrimp from both aquaculture and capture fisheries play a significant role in Indonesian export performance. "It's contributing 52 percent by value and 16 percent by volume to Indonesian export in 2003." 30 Also, some Indonesian exporters claim that steadily declined in Indonesian shrimp export from 2003 onwards, was caused by the appearance of new competitors like Thailand and Taiwan in the Japanese export market while at that time, Indonesian exporters were focused mainly in the United States market. Therefore, since 2005, they have been revitalized a shrimp export to Japan while enhancing market access to the United States.

By 2005 (January - March), Indonesian shrimp export to Japan reached about 11,657 tons which were accounted for about $16.62 \%$ of the total Japanese imported shrimp. In the same year, the United States offered a zero tax import facility for Indonesian shrimp export, as a result, in the first quarter of 2005 Indonesian shrimp export to this country reached 14,405 tons. ${ }^{31}$ Nowadays, among Indonesia's strength fishery products, shrimp might be the most prospective commodity, and it has been targeted by the Indonesian government to reach 350,000 tons, consisting of 110,000 tons of tiger prawn and 240 thousand tons of "vaname" shrimps. ${ }^{32}$

In fact, a challenge for Indonesian shrimp export is not solely dominated by business strategy, but also comes from the prevalence of strict

\footnotetext{
${ }^{28}$ Ibid.

29 'EU Asks Indonesia to Improve Quality of Fish Exports', Yahoo Asia News / Asia Pulse / Antara, (Jakarta) 9 December 2005

${ }^{30}$ Ibid.

${ }^{31}$ Rabo Bank, Revitalizing the Export Market for Indonesian Shrimp, (2006)

32 'Indonesia's shrimps production in 2006 projected at 350,000 tons', Antara News, [Jakarta], 31 August 2006
} 
requirement from importing countries on food safety. The European Union, for instance, since September 2001 required virus-free as well as antibioticfree shrimp imports. Respectively, in the same year, "the EU proceeded to examine 100 percent of shrimp products imported from China, Thailand, Vietnam, Indonesia and other countries because they discovered residual antibiotics in some products." ${ }^{33}$ Next, in 2004, Indonesia's shrimps have been detected to be infected by viruses and greatly contaminated by antibiotics such as oxytetracycline, chlortetracycline, and chloramphenicol. ${ }^{34}$

Indonesian Government, therefore, has restricted the use of chloramphenicol for animal health protection and as a supplement ingredient in animal feed, as well as in the harvest stage of cultivation. ${ }^{35}$ The Ministry of Marine Affairs and Fisheries, on March 2006, declared that the Indonesian government would adopt the international standards on exports of shrimp, in particular to the European Union and the United States. ${ }^{36}$

\section{b. Tuna}

Although fishing for tuna in Indonesia was industrialized in 1972, it began to be productive in the mid-1980s. In 2003, Indonesia was in the position of the third biggest producer of tuna in the world after Japan and Taiwan. According to Project Fish Report 2005, one-third of Indonesian catches consist of skipjack which is processed into canned tuna, as well as into dried, and smoked products (Fushi) for the Japanese market. Today, the main export markets for Indonesian canned tuna are the United States, the Middle East, and Northern Europe (the United Kingdom and Germany). ${ }^{37}$

Data from the Ministry of Maritime Affairs and Fisheries calculated that about 30.000 tonnes of canned tuna is produced per year, whilst the production of Fushi products is 7000 tonnes per year. However, as can be seen from the figure below, the Indonesian export of canned tuna decreased by approximately 10 percent from 1999 to $2002 .^{38}$

\footnotetext{
${ }^{33}$ Ibid., n.9, p.43 (Cited by Greenhalgh, 2004)

34 Kompas (3 Jan. 2004), 'Segera Benahi Udang untuk Meningkatkan Pangsa Pasar' (Reorganize Shrimp Business Immediately to Increase the Market Share). www.kompas.com

35 Oktaviani, Rina and Erwidodo, Managing the Challenges of WTO Participation: Case Study 18, 'Indonesia's Shrimp Exports: Meeting the Challenge of Quality Standards'. At the background section. Available online at: https://www.wto.org/english/res_e/booksp_e/casestudies_e/case18_e.htm

${ }^{36}$ Ibid., n.14.

${ }^{37}$ European Commission - Fisheries - Studies and Reports, The European Tuna SectorEconomic Situation Prospect and Analysis of the Impact of Liberalization to Trade-Specific Convention, SC 12-Final Report, (2005), pp. 155-156

${ }^{38}$ Ibid.
} 
Development of Indonesian Export of Canned Tuna 1999-2002

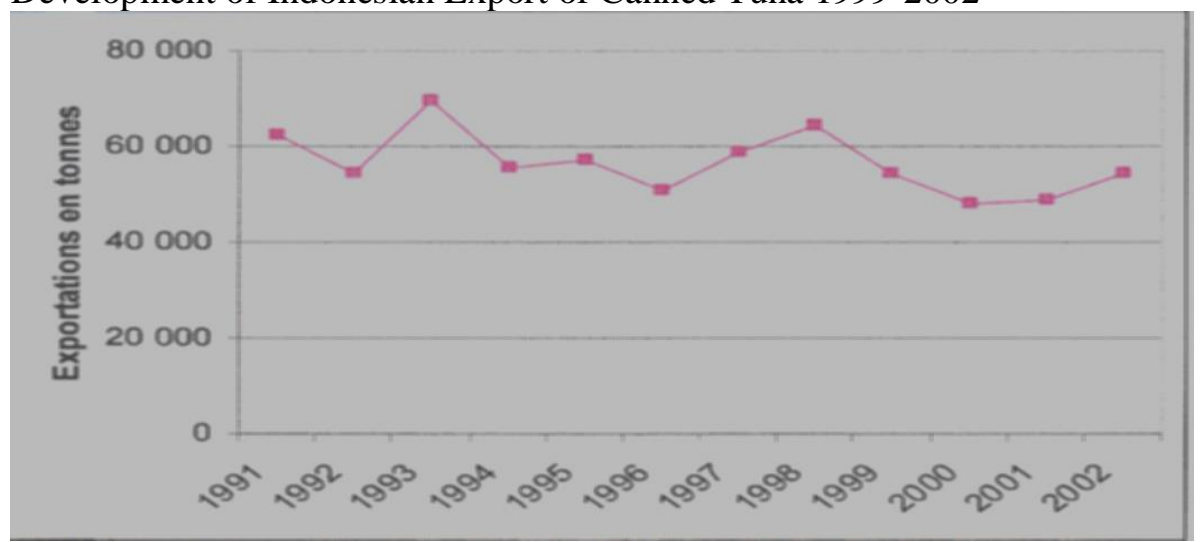

Source: FISHSTAT

The general director of the fishery at the Ministry of Maritime Affairs and Fishery, Husni Manggabarani, states that tuna processing industry and its marketing is experiencing significant problems about raw material supply, quality assurance, standardization and products certification. ${ }^{39}$

In the context of food safety, Indonesia is facing an embargo from European Union related to their strict requirement on food safety:

a. In 2004, EU imposed an embargo on frozen tuna steaks and fresh chilled yellow fine tuna loins (Thunnus Albacares) about histamine contamination in those products. EU dropped this embargo after received the explanation from Indonesian government that actions have been taken by the Indonesian government to comply the hygiene requirement, and that EU importers were particularly inattentive in shipping process which was contributed to histamine contamination. ${ }^{40}$

b. In 2005, The Community Inspection to Indonesia discovered serious evidence related to "hygiene in the handling of fishery products and the capacity of the Indonesian authority to carry out a reliable check of fish, in particular, to detect histamine and heavy metals." ${ }^{\text {11 }}$

c. European Union (EU) importers, in 2005, have asked Indonesia to improve the quality of its fishery products, particularly processed tuna. ${ }^{42}$

\footnotetext{
${ }^{39}$ Ibid., n.4.

${ }^{40}$ 'Embargo Produk Tuna oleh Uni Eropa Telah Dibatalkan (The European Union Has Withdrawn Its Tuna Embargo)', Tempo Interaktif-Ekonomi dan Bisnis, 08 September 2004

${ }^{41}$ Summary of Record of the Standing Committee on the Food Chain and Animal Health, Brussels 22 - 23 November 2005, SANCO-D.1 (06)D/410002

${ }^{42}$ Ibid., p.34.
} 
d. Currently, in June 2006, through its Rapid Alert System for Food and Feed (RASFF), EU imposed the Alert Notification for Indonesian frozen yellow fin tuna fillet (Thunnus Albacares), related mercury contamination. ${ }^{43}$

From the economic point of view, the above problems contributed to limited market access for tuna products, as EU has been the biggest importer of tuna products in the world. Moreover, in 2005, the Ministry of Maritime Affairs and Fishery claimed that "the financial loss from tuna products has reached 30 percent of its total production, with the selling price for sashimiclass tuna at IDR 48, 500 (US\$4.95) per kg." ${ }^{44}$ Therefore, the government should take into account, the increasingly demand of its trading partners on health and safety food by taking the innovative policies on fishery sector to gain back the economic potential of tuna as a large contributor to the country's foreign exchange income.

\section{Indonesian Fisheries Policy Reform: Compliance to Food/Seafood Standards}

Basically, as a member of the WTO (from 1995), Indonesia shall ensure the consistency of its implemented laws, regulations and administrative procedures, with the WTO agreements ${ }^{45}$, including the SPS Agreement. In practice, there is another major reason for Indonesia to comply with the challenging SPS requirements that are to secure its market access on fish and fishery products, particularly to the major trading partners like EU, the USA and Japan.

Law No. 31 of 2004 on Fisheries as the basic legal framework on fisheries in Indonesia, states the obligation of aquaculture farms and fish processing plants to apply a quality control method. Shortly, this regulation establishes the following sub-systems:

a. Quality monitoring and control;

b. Development and application of requirement or standards of raw materials, condition and standards for sanitation, and handling and cultivation techniques, requirements or standards of facilities and infrastructure, and requirements or standards of methods of examination; and

c. Certification ${ }^{46}$

However, both Act No.7/1996 on Food and Law No. 31/2004 on Fisheries, only regulates general provisions on food safety, particularly

\footnotetext{
${ }^{43}$ EU Rapid Alert System on Food and Feed (RASFF), Week 2006/25, 2006. BKE and 2006. BKF

${ }^{44}$ Ibid., p.34.

${ }^{45}$ WTO (1994)

${ }^{46}$ Fishery Law No.31/2004 (Indonesia) Article 20
} 
related to fish and fishery products that are not established in Act No.7/1996 on Food, albeit. While the quality management system on food production and processing is highly recognized in this regulation, it does not specifically reveal the guidelines to comply with this system. The Republic of Indonesia Act No. 7 of 1996 concerning Food is the most comprehensive legislation governing production, import, and distribution of foodstuffs. Although this was signed into force in November 1996, many of its provisions have not been enacted. The Act, for instance, included five clauses related to labeling of packaged food, but an adjacent clause states that an additional Government Regulation would further clarify four of those five clauses. In fact, until the required regulations are in force, the affected provisions of the Act Would not be forced.

Certain finding on the use of formalin in processed foods for domestic consumption has raised a question on the consistency of the authority to ensure the effective implementation of this regulation to protect human health. The Ministry of Marine Affairs and Fisheries (DKP) as the main fisheries authority in Indonesia, therefore has an essential role to break down the general provisions in the fisheries law into specific guidelines to ensure an effective operational of Indonesian food/seafood safety standards.

Afterward, Food Act No. 18 of 2012, the main legal framework for food safety in Indonesia, established as the basic legislation on Food as the essential human need and states that its fulfillment is part as human rights as guaranteed in the 1945 Constitution of the Republic of Indonesia. ${ }^{47}$ It defined food safety as the standards to prevent the contamination of food caused by biological contaminants, chemicals, or other elements that could endanger human health; also to ensure that it does not violate the rules of religion, belief, and community culture, so it is safe to be consumed. ${ }^{48}$ The Law has been implemented by Regulation of the Minister of Agriculture of RI No. 04/Permentan/PP. 340/2/2015 on the Food Safety Inspection on Plant Origin Fresh Food Import and Export.

However, the establishment of the national system on food safety in Indonesia is casuistic, depending on the requirements and standards imposed by importing countries. For years, non-compliance in the implementation of food safety measures in the importing countries still affects Indonesia's fisheries export. Strict food safety measures in the importing market tend to give problems to Indonesian fisheries when Indonesian fisheries still suffer food safety cases. Data from WTO and other institutions informed some refusal and notification alerts imposed by two major importer countries, i.e., Japan and the EU.

\footnotetext{
${ }^{47}$ Law of Food No. 18 on 2012 (In Bahasa Indonesia) Consideration: Point (a).

${ }^{48}$ Law of Food No. 18 of 2012 (In Bahasa Indonesia) Article 1, point 5.
} 
The number of refusal cases experienced by Indonesia's fisheries products in the US was also huge. Averagely it had more than $72 \%$ of the total case between 2004 and 2013. On the average, Indonesian fisheries contributed $64 \%$ to total food safety cases which faced by Indonesia's export commodities exported to Japan in the period between 2007 and 2013. As reported by the EU-RASFF (the Rapid Alert System for Food and Feed) ${ }^{49}$, there was a significant number of the food safety cases suffered by Indonesian fisheries products in the same period. It showed that $61 \%$ of the total food safety cases were faced by Indonesian fisheries, bigger than other foods and agricultural products. ${ }^{50}$

The above inconsistency could create legal uncertainty in the domestic fish and fishery industries as well, particularly small-scale industries, as they are vulnerable to regulatory changes due to a consequence to finance compliance. Consistency in applying the standard of food safety practices in the handling of fisheries products will serve to eliminate the restriction problems from the main importer countries, for instance, Japan and the EU. Government's active role in ensuring the implementation of standards of food safety practices can be done in various ways. For instance, the government can assist the producers to achieve the required food safety standards. Secondly, the government can also provide incentives or rewards to the producers or exporters who consistently comply with food safety standards in their production processes. Sanctions for violations, in contrary, may also be given to exporters who do not consistently comply with the prevailing regulations.

\section{a. The Integrated Fisheries Products Quality Management System}

The application of the integrated fishery products quality management system in Indonesia was begun in 1985 through the legislation of the former Indonesian Fisheries Law (Law No. 9/1985). It authorized the government to structure the quality assurance system on fishery products, to assure food quality and food safety and to prevent the economic fraudulent. Regarding hygiene requirements, the processing unit was required to apply the sanitation and hygiene standards that included: facilitation, environment, construction, tools, employees, sanitation process, raw materials, and final output, which were adopted from the Codex standard.

\footnotetext{
49 "A key tool to ensure the flow of information to enabling swift reaction when resks to public health are detected in the food chain." Can be accessed in: https://ec.europa.eu/food/safety/rasff_en

${ }^{50}$ Pusparani, Tika Nur, The Impact of Food Safety Measures Implementation on Indonesia's Exports of Fisheries, a Research Paper in partial fulfillment of the requirements for obtaining the degree of Master of Arts in Development Studies, The Hague, The Netherlands. P. 39. August, 2015.
} 
Respectively, in 1998, the Ministry of Agriculture has initiated a set of guidelines in relation to quality supervision and the control of fishery products, includes: "the Government regulation implementation of Decree No.41/Kpts/IK.210/1998 concerning Integrated Fish Product Quality Management System and Decree No.14128/Kpts/IK.130/1998 regarding Implementation Guidelines on Integrated Fish Product Quality Management System. ${ }^{" 51}$ Generally, these decrees obliged each processing unit to obtain Processing Properly Certificate and Fish Processing Certificate as well as the requirement to apply The Integrated Quality Management Programme based on Hazard Analysis Critical Control Point (HAACP).$^{52}$

Also, to assure the validity of quality control and supervision, the government was authorized to provide infrastructure to support handling and processing of products, except for the large-scale fisheries industries. Otherwise, this provision benefited the small-scale fisheries industries as their burden both on financial and technology will be reduced through the government infrastructure support.

Regarding the formation of the Ministry of Marine Affairs and Fisheries, in 1999, Decree of the Minister of Agriculture No.41/1998 re Integrated Fish Product Quality Management System was substituted by the Decree of the Minister of Marine Affairs and Fisheries No.1/2002 re Integrated Fish Product Quality Management System. Before the formation of the Ministry of Marine Affairs and Fisheries, any matter concerning fish and fisheries was under the authority of the Ministry of Agriculture.

While both decrees were concerning a similar substance, Decree of the Minister of Marine Affairs and Fisheries No.1/2002 regarding Integrated Fish Product Quality Management System contains more precise provisions on the certification system by stating a specific concern to some export destinations. It assert that based on Decree of the Directorate General of Fisheries No.14128/Kpts/IK.130/XII/98 (17 December 1998) regarding the Operational Guidelines of The Integrated Fish Quality Management System, every Fisheries Processing Unit, particularly with export destination to the EU, the USA, Canada and Australia, is obliged to apply for the Integrated Quality Certificate by proposed the Quality Manual of HACCP-Plan.

\section{b. The Quality Standardization: Opportunities and Challenges}

Regarding the quality standards, Decree of the Minister of Marine Affairs and Fisheries No.1/2002 affirm that the Indonesian National Standard (SNI) is the only authorized applied nationally in Indonesia. Otherwise, if the importing country required using their standard, the

\footnotetext{
${ }^{51}$ Ibid., p.32.

${ }^{52}$ Ibid.
} 
exemption may be given by the authority with the condition that their standard is equivalent to the Indonesian National Standard..$^{53}$ The SNI which was established by the National Standardization Institution (BSN) promotes effective production, as well as enhanced productivity and quality assurance on safe food production. Also, while the HAACP system was initially recognized in the former Indonesian Fisheries Law (Law No. 9/1985), it nationally was adopted under SNI No. 4852/1998. ${ }^{54}$

Simply, under the framework of WTO, some regulations are set up by the Indonesian authority to harmonize its food/seafood safety standards with the standards required by the SPS Agreement. Despite a successful issuance of these innovative policies, Indonesia is facing some serious obstacles to complying with dynamic food/seafood safety standardization, particularly on fish and fisheries export. Some observers assume that Indonesia similar to other developing countries are facing technical and financial difficulties to comply with food safety standards because of the obscurity of the SPS Agreement, particularly in defining the conceptions of Technical Assistance and Special and Differential Treatment. ${ }^{55}$

Some officials of the Indonesian authority, on the other hand, assert that the problems are not solely dominated by the lack of technology and financial support, but also caused by human negligence in handling and processing of products. An official from the Ministry of Marine Affairs and fisheries moreover claims that "Fish processing unit (UPI) has yet to improve sanitary and hygiene thus its processed products have often been contaminated, both from the tools and workers in the UPI." ${ }^{56}$ Others argue that another reason why Indonesian agricultural, including aquaculture, products are below the standards required by the consumers and the international market is that of the lack of food safety awareness in farmers. ${ }^{57}$

\section{c. Indonesian Fisheries Sector: Problems in Complying with the Food Safety Standards of the European Union}

Michael F. Jensen argues that "the existence of the SPS Agreement may catalyze regulatory reform. ${ }^{.58}$ It may motivate the member countries to reform their existing regulations and procedure by conformity with the SPS Agreement. In food/seafood safety standard, different countries may

\footnotetext{
53 Integrated Fish Product Quality Management System, Decree of the Minister of Marine Affairs and Fisheries No.1/2002 (Indonesia) Article 17

${ }^{54}$ FAO/WHO Global forum of Food Safety Regulators-Marrakesh-Marokko, Improving Efficiency and Transparency in Food Safety Systems-Sharing experiences, (2002)

${ }^{55}$ Direktorat Jenderal Perdagangan Luar Negeri (The Directorate General of Foreign Trade), Online Publication, (Jakarta) 1 January 2006

${ }^{56}$ Ibid., p. 27.

${ }^{57}$ Ibid., p.49.

${ }^{58}$ Ibid., p.5, p.33
} 
implement a different requirement in their domestic regulation. Moreover, some importing countries, notably the developed countries, often change their level of food safety standard to comply with their public interest in food safety. For the European Union, for instance, "food safety has become a major political issue both within the member states and the Commission, with a perceived need to demonstrate that consumer's interests are paramount and that a high level of precaution is applied to ensure food as safe as possible." 59

A problem mentioned above, in turn, creates uncertainty for the exporters about the state of food/seafood safety legislation in their export market. For a developing country exporter like Indonesia, it will be a crucial challenge to meet, as the development of its fisheries export is very depending on the market access provided by the major trading partners like EU, Japan, the USA, and Canada. Although the Indonesian legislation on quality supervision and control has been accepted to be equivalent by some of its trading partners, including EU which has asserted the equivalence of Indonesian regulation on quality supervision and control with Commission Decision No. 3245/94/EC, there is no guarantee for a lower pressure on Indonesian fisheries export.

As mentioned in the previous sections, Indonesia has received several notifications from its trading partners, mainly from EU, regarding the low food safety standard on Indonesian fish and fishery commodities, in particular on tuna and shrimp. About a later issue, some regulations have been established by the Indonesian government to ensure the equivalence of its food safety standards with the standards required by the biggest importing countries like EU, the USA, and Japan.

In 2004, when EU launched Council Directive No. 91/493/EEC, "laying down the health conditions for the production and the placing on the market of fishery products, ${ }^{, 60}$ the Indonesian authority responsively established Decree of the Minister of Marine Affairs and Fisheries No. 21/Men/2004 on Fisheries Product Quality Control and Supervision System for the European Union Market. This regulation has taken into account the importance of EU as a potential export destination of Indonesia fisheries commodities, as well as the specificity of fisheries quality control and supervision standards required by EU. ${ }^{61}$ Another item considered in this regulation is that the European Union obliged the exporting countries to apply the same standards on Fishery Products Quality Control and Supervision System with the standards referred to in Council Directive No. 91j493jEEC. Unfortunately,

\footnotetext{
${ }^{59}$ Ibid., p.1, p.107

${ }^{60}$ EU Council Directive No. 91/493/EEC

${ }^{61}$ Control and Supervision System of Fisheries Quality for EU Market, Minister Decree No.21/2004 (Indonesia) Consideration
} 
this proves the assumption of some developing countries that importing countries often oblige the "sameness' rather than "equivalence" by requiring the similarity, not only in the output, but also in the standardization. ${ }^{62}$ Michael F. Jensen, moreover, recognized this issue by stating that "The need of equivalence and not "sameness" is likely to increase in the future". ${ }^{63}$

However, there is evidence to prove that the importing countries, including EU, are often inconsistent with their standard. In this respect, Indonesia has recognized considerable difficulties regarding the dissimilarity of food/seafood safety standards imposed by the EU members. In 2004, EU declared an export embargo on fresh tuna produced by sixteen Indonesian fishery industries regarding histamine and mercury contamination. Responsively, Indonesian Ministry of Marine Affairs and Fisheries, Freddy Number, raised his objection on this allegation by stating that the histamine and mercury contamination was discovered in the grocery markets thus it has passed from the port of entry. ${ }^{64}$

Moreover, an official from the Ministry claimed; as the EU members have imposed a different standard on food/seafood safety, it seems that EU has imposed a double standard on fisheries export. ${ }^{65}$ For example, while EU has prohibited the importation of tuna products containing carbon monoxide, the Netherlands allowed the entrance of this product into its fisheries market. Problem occurs when the Netherlands then "re-exported" this commodity to the other EU members which may examine this product under the EU standard. ${ }^{66}$ As a result, the first exporter will be alleged for any contamination discovered in this assessment. Later on, an initiative proposed by EU Commission for a single certification system may resolve this problem. Mandelson, EU Trade Commissioner, argues that a more coherent voice in negotiating standards with EU trading partners may be achieved by EU if the members take into account the importance of a more coordinated export certifying system. ${ }^{67}$

Ironically, the practice of "re-export" moreover impedes the trade of Indonesian shrimp products. Recently, Indonesian trade Minister indicates that shrimp products which were discovered by EU as containing chloramphenicol, were, in fact, the products of that re-exported by some

\footnotetext{
${ }^{62}$ Ibid., p.5, p.24

${ }^{63}$ Ibid., p. 25

64 'Uni Eropa Menunda Ekspor Komoditas Perikanan (EU Imposed Export Embargo on Fisheries Products),' Tempo Interactive, (Jakarta) 06 May 2005

65 'Kepastian Pembukaan Larangan Ekspor Ikan Tuna September (A Confirmation to Withdraw Export Embargo on Tuna at September)', Tempo Interactive, (Jakarta) 07 May 2005

${ }^{66}$ Ibid.

${ }^{67}$ Mandelson, Peter, Speech in 'EU Exports and SPS Measures, Debate 2005:Twenty-five Stars or One Circle?', Organized by the Directorate General for Trade of the European Union
} 
Indonesian exporters. Although EU, in 2006, has lowered its inspection procedure against the Indonesian shrimp products, the Indonesian government has taken preventative anticipation by extending the prohibition of shrimp import, while tightening the conditions of issuance of import quality and health certificates to assure the originality of Indonesian shrimp export. ${ }^{68} \mathrm{~A}$ latter provision is also applying in regards to the increasing trend of transshipment via other countries by using Indonesia's export certificates. Recently, to reduce export barriers on shrimp products, the Indonesian authority has initiated the harmonization of its fisheries quality standard with the international quality standard and traceability refer to in Code of Conduct of Responsible Fisheries (CCRF) regulated by the World Food and Agriculture Organization (FAO). By mid-2006, Indonesia expects to establish a standardization and certification program for breeding, cultivation and post-harvest handling of shrimp. ${ }^{69}$

Nevertheless, the implementation of a new quality standard means the need to apply new technology, which is difficult and costly to meet by a developing country like Indonesia. Thus the need for technical and financial assistance from developed countries is inevitably essential. EU Trade Commissioner Peter Mandelson urges the EU countries to use trade-related assistance to assist importers from developing countries to invest in the capacity to comply with European and international standards and to obtain a maximum profit from the EU market access. ${ }^{70}$ However, as Mandelson asserted the need for better co-ordination between the WTO, the IMF, and the World Bank pertain to this commitment, it seems more complicated to be realized shortly. The other option to cope with this problem is to consider ASEAN proposal to establish a trust fund within the WTO that would channel technical assistance to the developing countries. ${ }^{71}$

The appointment of Susi Pudjiastuti in November 2014 as Minister of Ministry of Marine Affairs (KKP) was a headline item for Indonesia fisheries sector. In September 2015, Minister Susi Pudjiastuti announced the Strategic Plan 2015-2019 of the Ministry of Marine in the form of a Ministerial Decree, which makes it a legally binding document to which the Ministry of Marine Affairs (MMF) shall adhere. The Strategic Plan will help shape the MMAF's policy direction and priorities during the next five years. The Strategic Plan seeks to provide policy guidance in order to handle: Illegal fishing, unresolved maritime territorial disputes; lack of clear zoning

\footnotetext{
68 'Uni Eropa Cabut Pemeriksaan Udang Indonesia (The European Union to Withdraw Strict Inspection on Indonesian Shrimp),' Tempo Interactive, (Jakarta), 10 February 2006

69 'RI Akan Wajibkan Standar Kualitas FAO Untuk Udang (The Republic of Indonesia Requiring FAO Standard on Shrimp),' Warta Tanah Air , (Jakarta), March 2006

${ }^{70}$ Ibid.,p.62.

${ }^{71}$ Ibid.,p.5, p. 27
} 
regulations and low productivity in the aquaculture sector; low competitiveness and quality of fisheries products; tariff and lack of market access; as well as lack of access to capital and financing. ${ }^{72}$

There are several innovative movements on Indonesian fishery policies, as a result:

1. At the same year, Indonesia's Financial Services Authority (Otoritas Jasa Keuangan, or OJK), launched new programs to expand credit to maritime and fisheries sectors. New committed lending in 2015 rose to $\mathrm{Rp} 5.37$ trillion (U\$382.8 million) and is expected to reach or exceed $\mathrm{Rp}$ 10 trillion (US\$722.4 million) in 2016. ${ }^{73}$

2. Furthermore, the Ministry of Marine Affairs launched Ministerial Regulation No. 17/2015 concerning Criteria and Conditions for Granting Income Tax Deductions for Investments in Business Fields and/or regions related to Marine and Fisheries Sectors. This Ministerial Regulation establishing tax deduction for investments in business fields and/or regions are related to marine and fisheries sectors. ${ }^{74}$

3. In August 2015, Minister Pudjiastuti encourages the development of coastal airstrips, and announced that the government is encouraging private sector companies to build small airstrips to improve fishing communities' access to domestic and international markets. The effort currently relies on private sector companies CSR (corporate social responsibility) expenditures to build new airstrips for fishing communities, which is fully supported by the Government. ${ }^{75}$

4. October 2015: In a meeting between Indonesian President Joko Widodo and the US President Barack Obama, Indonesia and the US sign MOU on maritime cooperation which saw the elevation of bilateral ties to the level of "strategic partnership", the two sides signed a Memorandum of Understanding (MOU) on Maritime Cooperation to "deepen cooperation on maritime security, maritime economy, marine resources and fisheries conservation and management, maritime safety and navigation, marine science and technology, and other areas". It includes the improvement of capability to cope with data requirements of seafood traceability programs. ${ }^{76}$

\footnotetext{
${ }^{72}$ California Environmental Associates, 'Indonesia Fisheries; 2015 Review', A report on trends in coastal marine resources and fisheries management in Indonesia. Prepared for the David and Lucile Packard Foundation, (2015), p. 15.

${ }^{73}$ Ibid., p. 20

${ }^{74}$ Ibid., p. 21

${ }^{75}$ Ibid.

${ }^{76}$ The White House, "Joint Statement by the United States of America and the Republic of Indonesia" < $<$ https://www.whitehouse.gov/the-press-office/2015/10/26/joint-statement-unitedstates-america-and-republic-indonesia> and "Fact Sheet: U.S.Indonesia Maritime
} 


\section{d. Conclusion}

Great dependency on the market access of the developed importing countries may stimulate Indonesia to accept any requirement imposed by its trading partners. This is a problem of the majority of developing countries regarding the pervasiveness of strict SPS requirements on food/seafood safety imposed by major importing countries. In the fisheries sector, because of the strong linkages between this sector with livelihoods and development, including food security, the subsistence of artisanal fishing societies and invention of foreign exchange earnings, the Indonesian government, therefore, should take into account any change on food/seafood safety standard imposed by its trading partners. Another phenomenon has appeared to be considered that is importing countries may explicitly require the "sameness" and not the "equivalence" in the application of the standards on Fishery Products Quality Control and Supervision System to the developing countries, including Indonesia, because of distrust in the capability of developing countries to formulate an equivalent food/seafood safety. The importing countries, moreover, may require the implementation of their standards in a discriminative way. Any barrier to trade means an increased cost of trading.

It will have been better if the Indonesian government is consistent with its commitment to improving domestic food/seafood safety standards by enhancing a comprehensive implementation of The Integrated Fisheries Products Quality Management System. Regarding technical and financial assistance, it is important to develop multilateral and bilateral cooperation with major trading partners like the USA, EU, Japan or Canada to gain greater support in the spirit of mutual collaboration. From the legal perspective, the comprehensiveness and consistency of policymaking on food/seafood safety should be taken into account, as it will create legal certainty in domestic implementation, which in turn improve the trust of importing countries to the real capacity of Indonesia to manage food/seafood safety system. This, of course, should be supported by the WTO and the other competent organizations in this area by establishing a clearer guideline of the SPS agreement, with special regard to special and differential treatment, as well as technical and financial assistance.

Cooperation", (26 October 2015) <https://www.whitehouse.gov/the-pressoffice/2015/10/26/fact-sheet-us-indonesia-maritimecooperation>. 


\section{Bibliography}

\section{A. Books}

Anderson, Kym et al. (2001). The Economic of Quarantine and the SPS Agreement

California Environmental Associates. (2015). Indonesia Fisheries; 2015 Review, report on trends in coastal marine resources and fisheries management in Indonesia. Prepared for the David and Lucile Packard Foundation.

Landau. (2005). Alice International Trading System.

Matsushita, Mitsuo, et al. (2002). The World Trade Organization-Law, Practice and Policy

Pusparani, Tika Nur. (2015).The Impact of Food Safety Measures Implementation on Indonesia's Exports of Fisheries, a Research Paper in partial fulfillment, of the requirements for obtaining the degree of Master o Arts in Development Studies. The Hague, The Netherlands.

\section{B. Legislations}

Agreement on the Application of Sanitary and Phytosanitary Measures, reprinted in WTO, The Legal Text: The Result of The Uruguay Round of Multilateral Trade Negotiations 59 (1999) (From now on SPS Agreement)

Control and Supervision System of Fisheries Quality for EU Market, Minister Decree No.21/2004 (Indonesia)

EU Council Directive No. 91/493/EEC

EU Rapid Alert System on Food and Feed (RASFF), Week 2006/25 2006.BKE and 2006.BKF, available on http://ec.europa.eu/food/food/rapidalert/reports/week25-2006_en.pdf

Fishery Law No.31/2004 (Indonesia)

Integrated Fish Product Quality Management System, Decree of the Minister of Marine Affairs and Fisheries No.1/2002 (Indonesia)

Law of Food No.7/1996 (Indonesia)

Summary of Record of the Standing Committee on the Food Chain and Animal Health, Brussels 22 - 23 November 2005, SANCO-D.1 (06)D/410002, available

on http://ec.europe.eu/food/committee/regulatory/scfcah/controls_impor ts/summary47_en.pdf

The Domestic Regulations:

The European Union:

The Republic of Indonesia:

WTO (1994) 


\section{World Wide Web}

'EU Asks Indonesia to Improve Quality of Fish Exports,' Yahoo Asia News / Asia Pulse / Antara, [Jakarta] 9 December 2005, available on http://www.bkpm.go.id/bkpm/news.php?mode=baca\&info_id=252 1

Cato, JC., World (c), 20018, nsgd.gso.uri.edu

Direktorat Jenderal Perdagangan Luar Negeri (The Directorate General of Foreign Trade), [2006], available on http://www.djdaglu.go.id/sekretariat/index.php?id_menu=8\&id_su bmenu $=10$

Embargo Produk Tuna oleh Uni Eropa Telah Dibatalkan (The European Union Has Withdrawn Its Tuna Embargo)', Tempo InteraktifEkonomi dan Bisnis, 08 September 2004, available on http://www.tempointeraktif.com/hg/ekbis/2004/09/08/brk,20040908-

06,id.html

European Commission - Fisheries - Studies and Reports, The European Tuna Sector-Economic Situation Prospect and Analysis of the Impact of Liberalization to Trade-Specific Convention, SC 12-Final Report, [2005], available on http://ec.europa.eu/fisheries/publications/studies_reports_en.htm

FAO, Fish exports by developing countries help combat hunger, but better management needed, Newsroom, [2006], available on http://www.fao.org/newsroom/en/news/2006/1000301/index.html

FAO, Fisheries Global Information System, National Aquaculture Overview - Indonesia, [2006], available on http://www.fao.org/figis/servlet/static?dom=countrysector\&xml=n aso_indonesia.xml\#tcNE007D

FAO/WHO Global Forum of Food Safety Regulators-Marrakesh-Marokko, Improving Efficiency and Transparency in Food Safety SystemsSharing experiences, [2002], available on http://www.fao.org/docrep/meeting/004/Y3680E/Y3680E09.htm\#p 446_100978

Friis, M. Jensen, 'Reviewing the SPS Agreement: A Developing Country Perspective,' (2002), The Royal Veterinary and Agricultural University,5, available on http://www.tcd.ie/iiis/policycoherence/index.php/iiis/content/downlo ad/373/1454/file/Jensen\%20agreement.pdf

ICTSD - The International Centre for Trade and Sustainable Development, Fisheries, International Trade and Sustainable Development: Policy Discussion Paper, [2006], available on http://www.ictsd.org/ 
Indonesia's shrimp's production in 2006 projected at 350,000 tons', Antara News, [Jakarta], 31 August 2006, available on http://www.antara.co.id/en/seenws/?id=19195

Kepastian Pembukaan Larangan Ekspor Ikan Tuna September (A Confirmation to Withdraw Export Embargo on Tuna at September)', Tempo Interactive, (Jakarta) 07 May 2005, available on http://www.tempointeraktif.com/hg/ekbis/2005/05/07/brk,2005050706,id.html

Kompas (3 Jan. 2004), 'Segera Benahi Udang Untuk Meningkatkan Pangsa

Pasar' (Reorganize Shrimp Business Immediately to Increase the Market Share). www.kompas.com

Mandelson, Peter, Speech in 'EU Exports and SPS Measures, Debate 2005: Twenty-five Stars or One Circle?', Organized by the Directorate General for Trade of the European Union, available on http://tradeinfo.cec.eu.int/doclib/docs/2005/june/tradoc_123898.pdf

Mangunsong, Setia, 'Roadmap Management Mutu Hasil Perikanan ( The Roadmap of the Fisheries Quality Management System),' available on http://www.tokohindonesia.com/ensiklopedi/s/setiamangunsong/biografi/03.shtml

Nurdjana, Made L. (2006), 'Indonesia Aquaculture Development,' Paper presented at the RCA International Workshop on Innovative Technologies for Eco-Friendly Fish Farm Management and Production of Safe Aquaculture Food, Bali. Accessed in: www.agnet.org--htmlarea_file--library

Oktaviani, Rina, and Erwidodo Managing the Challenges of WTO Participation: Case Study 18, 'Indonesia's Shrimp Exports: Meeting the Challenge of Quality Standards.' Available online at https://www.wto.org/english/res_e/booksp_e/casestudies_e/case18 _e.htm

Rabo Bank, Revitalizing the Export Market for Indonesian Shrimp, [2006], available http://www.rabobank.com/content/offices/indonesia/news/1050801R evitalizingtheExportMarketforIndonesianShrimp.jsp

RI Akan Wajibkan Standard Kualitas FAO Untuk Udang (The Republic of Indonesia Requiring FAO Standard on Shrimp),' Warta Tanah Air, (Jakarta), March 2006, available on http://www.indonesiamrs.com/wta/wta2006/wtamaret06.pdf

Ruckes, E. 2000. Evolution of the International Regulatory Framework Governing International Trade in Fishery Products. Paper presented at the International Institute of Fisheries Economics and Trade 2000. Available online at http://oregonstate.edu/dept/IIFET/2000/abstracts/ruckes.html 
The White House, "Joint Statement by the United States of America and the Republic of Indonesia" <https://www.whitehouse.gov/the-pressoffice/2015/10/26/joint-statement-united-states-america-and-republicindonesia $>$ and "Fact Sheet: U.S.Indonesia Maritime Cooperation," (26 October 2015) <https://www.whitehouse.gov/the-pressoffice/2015/10/26/fact-sheet-us-indonesia-maritimecooperation>.

Uni Eropa Cabut Pemeriksaan Udang Indonesia (The European Union to Withdraw Strict Inspection on Indonesian Shrimp), Tempo Interactive, (Jakarta), 10 February 2006, available on http://www.tempointeraktif.com/hg/ekbis/2006/02/10/brk,2006021073738,id.html

Uni Eropa Menunda Ekspor Komoditas Perikanan (EU Imposed Export Embargo on Fisheries Products),' Tempo Interactive, (Jakarta) 06 May 2005, available on http://www.tempointeraktif.com/hg/ekbis/2005/05/06/brk,2005050603,id.html

United Nations Conference on Trade and Development, Commission on Trade in Goods and Services, and Commodities, Expert Meeting on Dynamic and New Sectors of World Trade, Trade, and Development Board, [2006], available on http://www.unctad.org/en/docs/c1em28d5_en.pdf

Zakariah Z. Maharani, 'The Implementation of Hazard Analysis and Critical Control Point (HAACP) by the Seafood Industry in Malaysia', available

on http://www.mima.gov.mymima/htmls/papers/pdf.zmz/haacp.pdf 